\title{
Threats to the image of the Polish Army
}

\author{
Grzegorz KLEIN, PhD.
}

\begin{abstract}
The article presents the most serious threats to the image of the Polish Army. The beginning of the research period was adopted in 2009 as the moment of starting the process of professionalization. It was a period in which missions outside the country were a particularly important threat to image. In the light of public opinion, nowadays the most serious threat is the partial politicization of the image of the army.

After identifying the most serious image threats, the problem of researchers was formulated and expressed in the question: how people and institutions responsible for creating the image of the Polish Army should counteract to the most serious image threats?

In this article, the recapitulated research was accompanied by the hypothesis that in order to counteract the most serious image threats, there should be an extension of civilian meaning and democratic control over the army. This control should include actions of state authorities protecting the military from the negative image-related effects of political decisions and ongoing political rivalry.
\end{abstract}

\section{Keywords}

Polish Army, army, Poland, image of the army, civilian and democratic control

\section{Introduction}

In his previous research on the image of the Polish Army, the author formulated the assumption according to which the image of the army is not only a value in itself, but also has a useful dimension. A good image can support the military operations even in such areas as: recruitment, modernization, information fight, strategic communication, crisis situations. Thus, for the research conducted in the field of national security, the following question is of great significance: how should people and institutions responsible for the image of the Polish Army use image opportunities, take image challenges, reduce image risks and counteract image threats? ${ }^{1}$ The research recapitulated in this work concerned the last of the mentioned issues, counteracting image threats.

In these studies, the time frame of 2009-2019 was adopted, starting with the year in which the process of professionalization of the Polish Army began. The basic element of this process was the full professionalization of the army (suspension of basic military service). One of the elements of this process was a change in the way people and institutions responsible

1 A similar perception of image issues may accompany reflections on shaping the image of other institutions ensuring security. 
for the image of the army act (including the launch of information and advertising activities encouraging professional and voluntary military service).

The research was based on a secondary analysis of the Public Opinion Research Center (CBOS), an institution which, on the basis of representative research groups, regularly (at least twice a year, in March and September) examines social assessments of the activities of public institutions in Poland (including the Polish Army). Each of the above mentioned studies was conducted on a nationwide representative random research group. ${ }^{2}$

The following table and chart present social assessments of the activities of the Polish Army in the period considered:

Table 1 Social evaluation of the activities of the Polish Army in 2009-2019

\begin{tabular}{|c|c|c|c|c|}
\hline $\begin{array}{l}\text { Evaluation of the activity army/ } \\
\text { date }\end{array}$ & Good & Bad & Hard to say & $\begin{array}{l}\text { Research } \\
\text { sample }\end{array}$ \\
\hline March 2009 & $75 \%$ & $6 \%$ & $19 \%$ & 977 \\
\hline September 2009 & $71 \%$ & $7 \%$ & $22 \%$ & 1,085 \\
\hline March 2010 & $66 \%$ & $6 \%$ & $28 \%$ & 995 \\
\hline April 2010 & $76 \%$ & $5 \%$ & $19 \%$ & 1,051 \\
\hline June 2010 & $73 \%$ & $5 \%$ & $22 \%$ & 977 \\
\hline September 2010 & $70 \%$ & $7 \%$ & $23 \%$ & 1,041 \\
\hline March 2011 & $64 \%$ & $8 \%$ & $28 \%$ & 948 \\
\hline September 2011 & $65 \%$ & $9 \%$ & $26 \%$ & 1,075 \\
\hline March 2012 & $66 \%$ & $9 \%$ & $25 \%$ & 1,013 \\
\hline September 2012 & $69 \%$ & $6 \%$ & $25 \%$ & 985 \\
\hline March 2013 & $55 \%$ & $10 \%$ & $35 \%$ & 1,057 \\
\hline September 2013 & $66 \%$ & $4 \%$ & $30 \%$ & 908 \\
\hline March 2014 & $66 \%$ & $8 \%$ & $26 \%$ & 1,093 \\
\hline September 2014 & $67 \%$ & $7 \%$ & $26 \%$ & 942 \\
\hline March 2015 & $62 \%$ & $8 \%$ & $30 \%$ & 1,056 \\
\hline September 2015 & $69 \%$ & $4 \%$ & $27 \%$ & 972 \\
\hline March 2016 & $66 \%$ & $6 \%$ & $28 \%$ & 1,033 \\
\hline September 2016 & $69 \%$ & $6 \%$ & $25 \%$ & 981 \\
\hline March 2017 & $60 \%$ & $12 \%$ & $28 \%$ & 1,018 \\
\hline September 2017 & $65 \%$ & $11 \%$ & $24 \%$ & 984 \\
\hline March 2018 & $59 \%$ & $8 \%$ & $33 \%$ & 1,090 \\
\hline September 2018 & $64 \%$ & $7 \%$ & $29 \%$ & 1,021 \\
\hline March 2019 & $73 \%$ & $10 \%$ & $17 \%$ & 1,044 \\
\hline
\end{tabular}

Source: own elaboration based on: Komunikat z badań (Statement of research) number: 43/2016, 10; 44/2019, 10, CBOS, Warszawa [Warsaw]

2 Detailed information on the methods of conducting research can be found on the website of CBOS Foundation: Metody realizacji badań (Research realization methods), online: https://www.cbos.pl/PL/badania/metody_realizacji.php; Research, online: https://www.cbos.pl/EN/research/research.php. 
Figure 1 Social evaluation of the activities of the Polish Army in 2009-2019

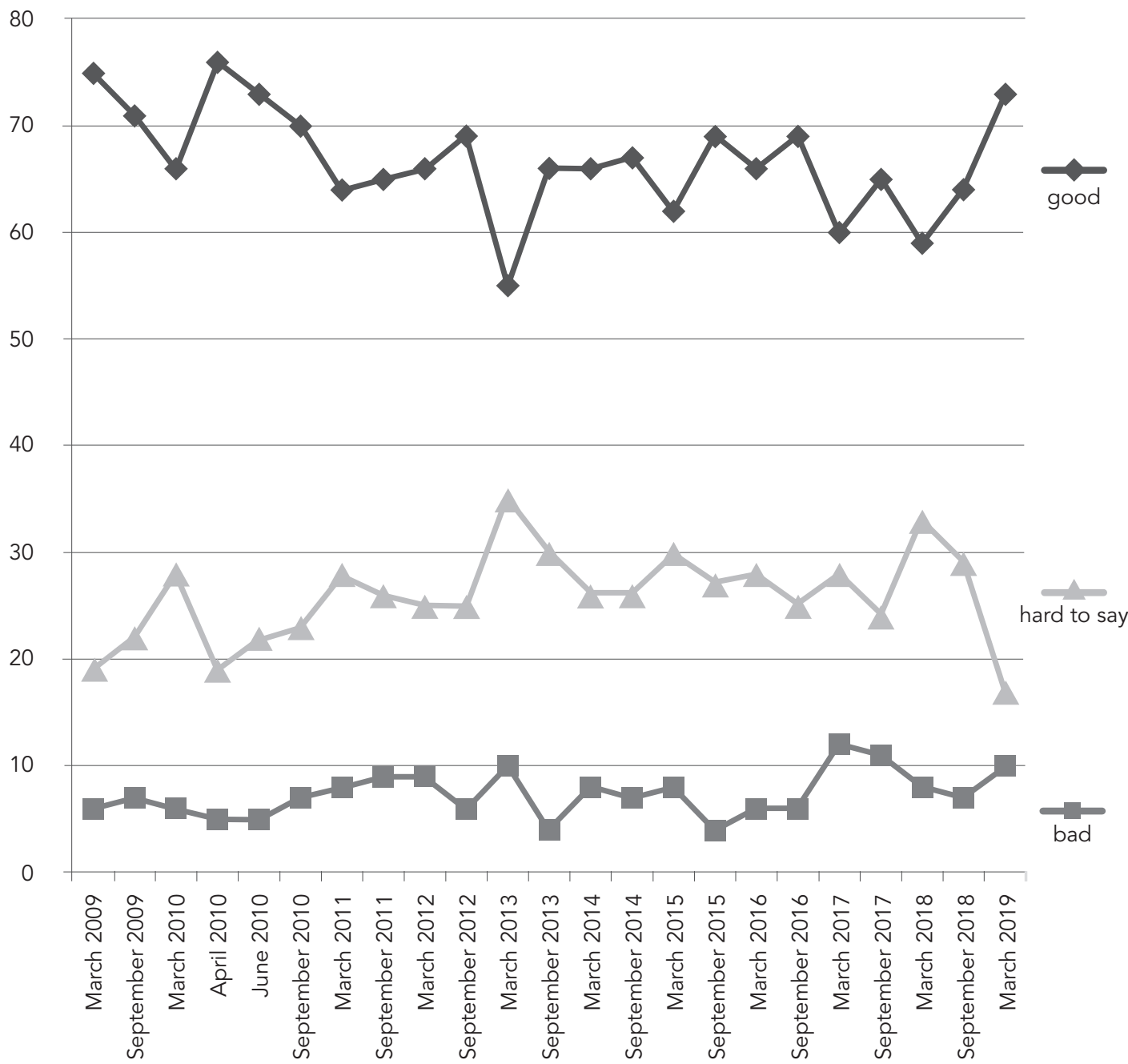

Source: own elaboration based on: Komunikat z badań (Statement of research) number: 43/2016, 10; 44/2019, 10, CBOS, Warszawa [Warsaw]

The above data does not allow to distinguish the mentioned image threats. In order to identify them, it was necessary to conduct an in-depth analysis including annex tables ${ }^{3}$ and to analyze CBOS surveys relating to the social assessment of the involvement of the Polish Army in missions in Iraq and Afghanistan.

The first part of this paper presents general remarks concerning the shaping of the image of the Polish Army. The ways of understanding this issue by military and civil decision-makers

3 The annex tables are not available for each of the tests provided in Table 1 and Figure 1. The article contains an analysis based on all tables provided by CBOS. 
after 1989 were discussed. This part also includes a list of the most important opportunities, challenges and threats to the image of the Polish Army after 2009, as well as an introductory description of image threats.

In the second part of the article, the analysis of the involvement of the Polish Army in specific missions abroad was made, and therefore the activities that at the beginning of the period considered were the biggest threat image.

The third part is a secondary analysis of CBOS research on image threats related to the partial politicization of social assessments of the Polish Army's activities after the change of government in 2015.

The last part presents the basic ways of understanding civil and democratic control over the army and its legal bases in Poland. This part also includes a postulate to change the way of civilian perception and democratic control, so that through it civilian decision-makers can protect the military against image threats having a political dimension.

\section{Shaping the image of the Polish Army: general remarks}

The author's research so far has enabled to distinguish two periods in shaping the image of the Polish Army after 1989. They are separated by the process of professionalization of the Polish Army. This process was initiated by a political decision issued in 2007, which culminated with a fundamental element in 2009. It was the year in which the compulsory military service was suspended. The professionalization of the army also meant a change in the approach to shaping the image of the Polish Army. Civilian and military decision-makers had to take action to attract candidates for professional soldiers from the labour market. This forced, among others, the need to undertake activities promoting service in the army (these activities were carried out, among others, in the media). The process of shaping the image of the Polish Army as a professional and modern institution, which ensures security and is an attractive employer, has begun.

Before the professionalization process, the Polish Army hardly took any actions shaping the image. The actions taken were mostly related to celebrating holidays (state or individual units). These activities lacked a coherent and long-term vision. This was, among others, a result of the military decision-makers' conviction that activities of the army in the media space may be associated by journalists with propaganda from before 1989, and therefore the army should not be promoted in the media.

The adopted division may be reflected in the state of Polish scientific literature in the field of reflection on shaping the image of the army - before 2009 few publications appeared and they were mainly advisory in nature (e.g. they contained advice on how to organize a press conference). It was only professionalization that resulted in an increase in the interest of researchers in the subject of military image. ${ }^{4}$

The applied division does not mean that after 2009 the activities of military and civilian decision-makers in terms of creating the image of the army were characterized only by professionalism. An example is the approach to provisions regulating information activities in the military. In the decision issued in 2009 by the Minister of National Defence con-

4 KLEIN, Grzegorz: Kształtowanie wizerunku Wojska Polskiego jako instytucji zapewniającej bezpieczeństwo, Warszawa [Warsaw] 2019, 15-16, 20, 29-30. 
cerning the information policy of the Ministry of National Defence, it was assumed that the Director of the Press and Information Department of the Ministry of National Defence would be responsible for implementation of these activities. After the change of government in 2015-2016, structural changes were introduced in the Ministry, as a result of which the Press and Information Department ceased to exist. The Decision in its wording (thus entrusting responsibility to the Director of the non-existing Department) was valid in March 2019, when a new Decision was issued. ${ }^{5}$

Research conducted so far by the author has enabled to classify the process of professionalization into a group of image challenges, i.e. activities that may become in time image opportunities (image of a modern, professional army) or threats (risks related to e.g. social perception of modernization programs, their purpose and related costs). Other image challenges include creation of the Territorial Defence Forces, i.e. a volunteer formation, which in the opinion of supporters, may strengthen the potential of the Polish Army and, in the opinion of critics, weakens this potential (by operating "at the expense" of operational units). Moreover, this formation has a politicized image resulting from the formation of the former Minister of National Defence, Antoni Macierewicz - this politician evokes extremely different emotions in Polish society, his biggest opponents treat the Territorial Defence Forces as the "Macierewicz Army" or the "PiS Army".

Image chances result from the fact that the image of the Polish Army is rooted in the society, thus they are based on Polish history and culture. However, the image threats (after 2009) are mainly missions outside the country and politicization of the army in the perception of a part of the media and society. ${ }^{6}$

The first of image threats resulted primarily from the mission nature in Iraq and Afghanistan. The first one from the very beginning, the second one after a few years of relatively low involvement, had an unambiguous combat dimension. This was related to the risk of losses among Polish soldiers. At the beginning of the first mission there were 2,500 Polish soldiers in each shift (2003-2004, in later years the number of contingents was decreasing). During this period 22 soldiers and one officer of the Government Protection Bureau died. The second mission at its peak (2010-2012) consisted of about 2,500 soldiers within each contingent. During this mission 43 soldiers and 2 employees of the army were killed. These losses were all the more unacceptable for the society, because (as shown in the CBOS survey cited hereafter) the majority of society did not believe that these missions would contribute to peace. The majority of Poles did not see any reason why Polish soldiers had to take part in such large numbers in distant and dangerous missions. Moreover, these missions showed deficiencies in the equipment and training of Polish soldiers and aggregated significant costs.

The second of the image threats results from deepening of political divisions within the Polish society. Until the change of government, the army was assessed in a similar way

5 Decision of the Minister of National Defence No. 108/MON of 7 April 2009 on the principles of implementing the information policy of the Ministry of National Defence, Official Journal of the Minister of National Defence, 2009, No. 7, item 82; Decision of the Minister of National Defence No. 47/MON of 26 March 2019 on the principles of implementing the information policy and functioning of the social communication service in the Ministry of National Defence, Official Journal of the Minister of National Defence, 2019, item 56; KLEIN, Kształtowanie..., 104-105.

6 Ibidem, 183-200. 
by respondents declaring right-wing and left-wing views. On the basis of research results quoted below in this paper, it should be concluded that the image of the army has been partially politicalized. It can be assumed that this results not only from the actions of politicians, but also from the media, which by favoring particular political options, create messages that strengthen social divisions.

The media also contributed to shaping public opinion on the first threat. The author's research on the media discourse concerning the missions in Iraq and Afghanistan allowed the following conclusion to be drawn: "The media wrote about missions mainly in the context of problems - human losses, costs, equipment shortages. To this end, the military and those in power were criticized for their inability to convince the public that such involvement is necessary". ${ }^{7}$

\section{Image threats related to the missions of the Polish Army in Iraq and Afghanistan}

In order to identify the image threat associated with the missions in Iraq and Afghanistan, the results of CBOS surveys concerning:

- support for the participation of Polish soldiers in the NATO operation in Afghanistan;

- whether the NATO mission in Afghanistan will contribute to the preservation of peace in this country;

- whether the mission in Afghanistan should be continued or completed;

- the type of engagement of Polish soldiers in the mission in Afghanistan;

- the risk of attacks on Poland by Muslim fundamentalists in connection with the missions in Iraq and Afghanistan;

- support for the participation of Polish soldiers in operations in Iraq;

- the level of government reporting on its intentions in the context of the mission in Iraq and Afghanistan;

- participation of the Polish Army in international military missions (such as missions in Iraq and Afghanistan) in relation to the economic potential and financial capabilities of Poland.

In February 2009, $22 \%$ of CBOS respondents supported the participation of Polish soldiers in the NATO operation in Afghanistan (5 \% "I strongly support", $17 \%$ "I rather support"). In September 2009, 20 \% of respondents expressed their support (5 \% "I strongly support", $15 \%$ "I rather support"). In the surveys of November 2010, $17 \%$ of respondents expressed their support (6 \% "I strongly support", $11 \%$ "I rather support"). Starting from 2007, ${ }^{8}$ support never exceeded $22 \%$, the lowest - in December 2007 it was $14 \%$.

Lack of support for the participation of Polish soldiers in the NATO operation in Afghanistan in February 2009 was expressed by 73 \% of respondents (29\% "I rather do not support", $44 \%$ "I definitely do not support"). In September 2009, 76 \% of respondents declared a lack of support (28 \% "I rather do not support", $48 \%$ "I definitely do not support").

7 KLEIN, Grzegorz: Obraz Wojska Polskiego w prasie w świetle zaangażowania w misje poza granicami kraju, in: Zeszyty Naukowe Bezpieczeństwo i Administracja, 2014, 4, 219.

8 This question was asked to respondents in January, June, July, September, October and December 2007, February, April and September 2008, February and September 2009 and in November 2010. 
In a study from November $2010,79 \%$ of respondents expressed no support (26\% "I rather do not support", 53 \% "I definitely do not support"). Lack of support, the respondents most often declared in December 2007 (83 \%), and the least frequently in September 2007 (72 \%). The answer "hard to say" in February 2009 was declared by $5 \%$ of respondents, in September 2009 and in November 2010, 4 \% of respondents chose such a response. The highest percentage of "hard to say" answers (6\%) is the study from September 2007, and the lowest (3\%) is the study from December 2007.

With almost the same intensity, the CBOS asked the respondents a question about whether the NATO mission in Afghanistan would contribute to the preservation of peace in this country. ${ }^{9}$ In September 2009, an affirmative answer was expressed by $17 \%$ of respondents (2 \% "definitely yes", $15 \%$ "rather yes"). In November 2010, $16 \%$ of respondents chose such a response (3\% "definitely yes", $13 \%$ "rather yes"). The highest percentage of respondents chose this answer in September 2007 (21\%), the smallest (16\%) in June and July 2007 and in November 2010.

In September 2009, $71 \%$ of respondents said that the NATO mission in Afghanistan would not contribute to the preservation of peace in this country (44\% "rather not", $27 \%$ "definitely not"). In November 2010, $71 \%$ of respondents also chose the answer (40 \% "rather not", 31\% "definitely not"). Most often, respondents declared such an answer in October 2007 (73 \%), and the least frequently in September 2007 (61\%).

In September 2009, 12 \% of respondents chose the answer "hard to say", in November 2010 this answer was declared by $13 \%$. Respondents chose this answer most often in September 2007 (18\%), least frequently in September 2009.

In June $2009,65 \%$ of respondents said that the mission in Afghanistan should be terminated, $27 \%$ said that the mission in Afghanistan should be continued, $8 \%$ chose the answer "hard to say". In September, the answers were at $77 \%, 16 \%$ and $7 \%$, respectively.

In November 2010, when asked about the type of engagement of Polish soldiers in missions in Afghanistan, $60 \%$ of respondents said that they should not participate in this mission, $30 \%$ declared that they should not conduct military activities, $7 \%$ said they should continue their activities in an unchanged form (thus along with conducting armed operations), and $3 \%$ of respondents chose the answer "hard to say". In the research carried out in 2007 , the responses were at $60 \%, 32 \%, 5 \%$, and $3 \%$, respectively.

In November 2010, the CBOS asked respondents whether the involvement of Polish soldiers in the mission in Afghanistan could cause attacks by Muslim fundamentalists in Poland. ${ }^{10}$ No worries were declared by $35 \%$ of respondents (8 \% "I'm not afraid", 27 \% "I'm not rather afraid"). Respondents usually chose this answer in November 2010, the least often in November 2007 (27\%).

In November 2010, $56 \%$ of the respondents were of the opposite opinion ( $45 \%$ "I'm rather afraid", $11 \%$ "I'm very afraid"). Respondents usually chose the answer in November 2007 (65\%), and the least frequently in November 2010.

9 This question was asked to respondents in June, July, September and October 2007, February, April and September 2008, September 2009 and November 2010.

10 This question was also asked in November 2007 and in April and September 2008. In the first two studies, the question also concerned the involvement of the Polish Army in the mission in Iraq. 
The answer "hard to say" was chosen in November 2010 by $9 \%$ of respondents. Respondents most often chose this answer in April 2008 (10\%), least often in September $2008(7 \%){ }^{11}$

Even before the professionalization process began (marking the beginning of the research period), the CBOS asked respondents a question about their support for the mission of the Polish Army in Iraq. ${ }^{12}$ The maximum level of response "I support" is January 2004 (42 \%), the smallest level is June 2007 (15\%). The answer "I do not support" the respondents most often chose in June and October 2007 (81\%), the least often in September 2003 and January 2004 (53\%). The answer "hard to say" was most often chosen by the respondents in September 2003 (7 \%), most seldom in October 2004, March 2005, August and October 2007 (3\%). ${ }^{13}$

Also before the professionalization process began, the CBOS asked the respondents how they assessed the government's informing about its intentions, including on the participation of Polish soldiers in missions in Iraq and Afghanistan. Regarding the mission in Iraq, $21 \%$ of the respondents considered the information measures sufficient (2\% "definitely sufficient", $19 \%$ "rather adequate"), the opposite opinion was $70 \%$ of respondents (45\% "rather inadequate", $25 \%$ "definitely insufficient") and $9 \%$ chose the answer "hard to say". Regarding the mission in Afghanistan, the government's information activities were sufficiently recognized by $18 \%$ of respondents (2\% "definitely sufficient", $16 \%$ "rather adequate"), the opposite was $73 \%$ of respondents (43\% "rather inadequate", 30 \% "definitely insufficient") and $9 \%$ chose the answer "hard to say". ${ }^{14}$

In 2009, the CBOS asked the respondents a question regarding the participation of the Polish Army in international military missions (such as bears in Iraq and Afghanistan) in relation to the economic potential and financial capabilities of Poland. According to $56 \%$ of respondents, this share was too large, $17 \%$ considered this share as adequate, $10 \%$ was too small, and $17 \%$ chose the answer "hard to say". ${ }^{15}$

The research results quoted above can be considered individually, but in the context of image threats, it is cognitively valuable to synthesize them. If we formulate a one-sentence synthesis of the social assessment of the Polish Army's involvement in activities such as missions in Iraq and Afghanistan, this sentence could read as follows: the majority of Polish society is against such missions, recognizing that they do not bring peace, they endanger Poland; it's expensive, and government does not inform them about it. This sentence is a simplistic affirmation with a journalistic connotation, but its syntax allows for the unambiguous inclusion of this type of mission in the catalogue of potential threats to the image of the Polish Army.

11 Own study based on: Komunikat z badań (Statement of research) number: 127/2009 (research sample: 1086); 159/2010 (research sample: 999), CBOS Warszawa [Warsaw].

12 This question was asked between August and December 2003, each month of 2004, in January, February, March, May and December 2005, January 2006 and January, June and October 2007.

13 Komunikat z badań (Statement of research) number: 162/2007 (research sample: 1385), CBOS Warszawa [Warsaw], 2.

14 Komunikat z badań (Statement of research) number: 134/2007 (research sample: 859), CBOS Warszawa [Warsaw], 2.

15 Komunikat z badań (Statement of research) number: 144/2009 (research sample: 1086), CBOS Warszawa [Warsaw], 6. 
In Polish strategic documents, such as the National Security Strategy (2014), the development and cooperation within NATO and cooperation with the US was considered one of the priorities of the Polish security policy. ${ }^{16}$ One can assume that the development of this cooperation is prioritized by the most important political parties in Poland. This is evidenced not only by public declarations of politicians, but also by their approach to relations with the USA and allied cooperation within NATO in the context of the mission in Iraq and Afghanistan. The beginning of these missions was the SLD government, which was then continued during the coalition of the PiS-Samoobrona-LPR and the PO-PSL coalition. This allows us to assume that if in the future a military alliance would emerge under the auspices of the US or NATO, the mission, in line with measures taken in Iraq or Afghanistan, Poland's participation in such a mission can be considered probable. If so, then the potential threats to the image of the Polish Army related to involvement in such missions will become valid again. It would therefore be valuable to work out ways to counter such threats.

\section{Threats related to the partial politicization of social assessments of the activities of the Polish Army}

Secondary analysis of CBOS surveys on the evaluation of the activities of the Polish Army depending on the political views declared was carried out in three parts. The first part presents the answers "hard to say", in the second assessment "good", in the third answer "bad". In each part, answers of respondents declaring centrist, left views and right views were presented separately. Within each of these groups, there were divided into two periods - from 2009 to 2015 and from 2016 to $2019 .{ }^{17}$ A comparison of these periods was also made, thus showing how the average responses changed after each change in each group government, which took place at the end of 2015.

\section{Answers "hard to say":}

Subjects declaring centrist views:

Table 2 Answers "hard to say" among declaring centrist views, 2009-2015

\begin{tabular}{|c|c|c|c|c|c|c|c|c|c|c|c|}
\hline $\begin{array}{c}\text { March } \\
2009\end{array}$ & Sept. & April & March & Sept. & March & March & Sept. & March & Sept. & March & Sept. \\
2015 & 2010 & 2011 & 2011 & 2012 & 2013 & 2013 & 2014 & 2014 & 2015 \\
\hline $20 \%$ & $22 \%$ & $13 \%$ & $22 \%$ & $25 \%$ & $17 \%$ & $30 \%$ & $31 \%$ & $25 \%$ & $24 \%$ & $27 \%$ & $19 \%$ \\
\hline
\end{tabular}

Source: own elaboration based on: Komunikat z badań (Statement of research) number: 42/2009; 126/2009; 54/2010; 30/2011; 108/2011; 39/2012; 44/2013; 130/2013; 36/2014; 131/2014; 42/2015; 131/2015, CBOS,

16 "Membership in Euro-Atlantic and European cooperation structures strengthens the security of the Republic of Poland. NATO is the most important form of political and military cooperation between Poland and the allies. The European Union supports the socio-economic development of Poland and strengthens its position in the world. The most important non-European partner of Poland remains the United States of America", National Security Strategy of the Republic of Poland, Warsaw 2014, pts. 6, 9.

17 Research samples were quoted in Table 1. 
Table 3 Answers "hard to say" among declaring centrist views, 2016-2019

\begin{tabular}{|c|c|c|c|c|c|}
\hline $\begin{array}{c}\text { March } \\
2016\end{array}$ & $\begin{array}{c}\text { March } \\
2017\end{array}$ & $\begin{array}{c}\text { September } \\
2017\end{array}$ & $\begin{array}{c}\text { March } \\
2018\end{array}$ & $\begin{array}{c}\text { September } \\
2018\end{array}$ & $\begin{array}{c}\text { March } \\
2019\end{array}$ \\
\hline $23 \%$ & $25 \%$ & $22 \%$ & $29 \%$ & $24 \%$ & $13 \%$ \\
\hline
\end{tabular}

Source: own elaboration based on: Komunikat z badań (Statement of research) number: 43/2016; 32/2017; 124/2017; 40/2018; 121/2018; 44/2019, CBOS, Warszawa [Warsaw]

Table 4 The average answer "hard to say" among declaring centrist views, 2009-2015 and 2016-2019

\begin{tabular}{|c|c|c|}
\hline \multirow{2}{*}{$\begin{array}{c}\text { The average answer "hard to say" } \\
\text { among declaring centrist views }\end{array}$} & $2009-2015$ & $2016-2019$ \\
\cline { 2 - 3 } & $23 \%$ & $23 \%$ \\
\hline
\end{tabular}

Subjects declaring leftist views:

Table 5 Answers "hard to say" among declaring leftist views, 2009-2015

\begin{tabular}{|c|c|c|c|c|c|c|c|c|c|c|c|}
\hline $\begin{array}{c}\text { March } \\
2009\end{array}$ & $\begin{array}{c}\text { Sept. } \\
2009\end{array}$ & $\begin{array}{c}\text { April } \\
2010\end{array}$ & $\begin{array}{c}\text { March } \\
2011\end{array}$ & $\begin{array}{c}\text { Sept. } \\
2011\end{array}$ & $\begin{array}{c}\text { March } \\
2012\end{array}$ & $\begin{array}{c}\text { March } \\
2013\end{array}$ & $\begin{array}{c}\text { Sept. } \\
2013\end{array}$ & $\begin{array}{c}\text { March } \\
2014\end{array}$ & $\begin{array}{c}\text { Sept. } \\
2014\end{array}$ & $\begin{array}{c}\text { March } \\
2015\end{array}$ & $\begin{array}{c}\text { Sept. } \\
2015\end{array}$ \\
\hline $18 \%$ & $21 \%$ & $13 \%$ & $20 \%$ & $19 \%$ & $17 \%$ & $30 \%$ & $24 \%$ & $15 \%$ & $24 \%$ & $28 \%$ & $22 \%$ \\
\hline
\end{tabular}

Source: own elaboration based on: Komunikat z badań (Statement of research) number: 42/2009; 126/2009; 54/2010; 30/2011; 108/2011; 39/2012; 44/2013; 130/2013; 36/2014; 131/2014; 42/2015; 131/2015, CBOS,

Table 6 Answers "hard to say" among declaring leftist views, 2016-2019

\begin{tabular}{|c|c|c|c|c|c|}
\hline $\begin{array}{c}\text { March } \\
2016\end{array}$ & $\begin{array}{c}\text { March } \\
2017\end{array}$ & $\begin{array}{c}\text { September } \\
2017\end{array}$ & $\begin{array}{c}\text { March } \\
2018\end{array}$ & $\begin{array}{c}\text { September } \\
2018\end{array}$ & $\begin{array}{c}\text { March } \\
2019\end{array}$ \\
\hline $28 \%$ & $25 \%$ & $21 \%$ & $31 \%$ & $29 \%$ & $15 \%$ \\
\hline
\end{tabular}

Source: own elaboration based on: Komunikat z badań (Statement of research) number: 43/2016; 32/2017; 124/2017; 40/2018; 121/2018; 44/2019; CBOS, Warszawa [Warsaw]

Table 7 The average answer "hard to say" among declaring leftist views, 2009-2015 and 2016-2019

\begin{tabular}{|c|c|c|}
\hline The average answer "hard to say" & $2009-2015$ & $2016-2019$ \\
\cline { 2 - 3 } among declaring leftist views & $21 \%$ & $25 \%$ \\
\hline
\end{tabular}


Subjects declaring right-wing views:

Table 8 Answers "hard to say" among declaring right-wing views, 2009-2015

\begin{tabular}{|c|c|c|c|c|c|c|c|c|c|c|c|}
\hline $\begin{array}{c}\text { March } \\
2009\end{array}$ & $\begin{array}{l}\text { Sept. } \\
2009\end{array}$ & $\begin{array}{l}\text { April } \\
2010\end{array}$ & $\begin{array}{c}\text { March } \\
2011\end{array}$ & $\begin{array}{l}\text { Sept. } \\
2011\end{array}$ & $\begin{array}{c}\text { March } \\
2012 \\
\end{array}$ & $\begin{array}{c}\text { March } \\
2013\end{array}$ & $\begin{array}{l}\text { Sept. } \\
2013\end{array}$ & $\begin{array}{c}\text { March } \\
2014\end{array}$ & $\begin{array}{l}\text { Sept. } \\
2014\end{array}$ & $\begin{array}{c}\text { March } \\
2015\end{array}$ & $\begin{array}{l}\text { Sept. } \\
2015\end{array}$ \\
\hline $13 \%$ & $14 \%$ & $17 \%$ & $25 \%$ & $24 \%$ & $20 \%$ & $29 \%$ & $25 \%$ & $23 \%$ & $21 \%$ & $26 \%$ & $24 \%$ \\
\hline
\end{tabular}

Source: own elaboration based on: Komunikat z badań (Statement of research) number: 42/2009; 126/2009; 54/2010; 30/2011; 108/2011; 39/2012; 44/2013; 130/2013; 36/2014; 131/2014; 42/2015; 131/2015, CBOS, Warszawa [Warsaw]

Table 9 Answers "hard to say" among declaring right-wing views, 2016-2019

\begin{tabular}{|c|c|c|c|c|c|}
\hline $\begin{array}{c}\text { March } \\
2016\end{array}$ & March & September & March & September & $\begin{array}{c}\text { March } \\
2019\end{array}$ \\
\hline $21 \%$ & 2017 & 2017 & 2018 & 2018 & $13 \%$ \\
\hline
\end{tabular}

Source: own elaboration based on: Komunikat z badań (Statement of research) number: 43/2016; 32/2017; $124 / 2017 ; 40 / 2018 ; 121 / 2018 ; 44 / 2019$, CBOS, Warszawa [Warsaw]

Table 10 Average of answers "hard to say" among declaring right-wing views, 2009-2015 and 2016-2019

\begin{tabular}{|l|c|c|}
\hline \multirow{2}{*}{$\begin{array}{l}\text { Average of answers "hard to say" } \\
\text { among declaring right-wing views }\end{array}$} & $2009-2015$ & $2016-2019$ \\
\cline { 2 - 3 } & $22 \%$ & $21 \%$ \\
\hline
\end{tabular}

Source: own elaboration

Respondents declaring central views of the answer "hard to say" for the years 2009-2015 and 2016-2019 expressed at the same level. Among respondents declaring left-wing views, the average of such answers increased by 4 percentage points. In the respondents declaring right-wing views, the average rating "hard to say" dropped by 1 percentage point. The presented changes do not allow to formulate the conclusion that there has been a politicization of the social assessment of the activities of the Polish Army.

\section{Answers "good":}

Subjects declaring centrist views:

Table 11 Answers "good" among declaring centrist views, 2009-2015

\begin{tabular}{|c|c|c|c|c|c|c|c|c|c|c|c|}
\hline $\begin{array}{c}\text { March } \\
2009\end{array}$ & Sept. & April & March & Sept. & March & March & Sept. & March & Sept. & March & Sept. \\
2010 & 2011 & 2011 & 2012 & 2013 & 2013 & 2014 & 2014 & 2015 & 2015 \\
\hline $73 \%$ & $69 \%$ & $81 \%$ & $73 \%$ & $67 \%$ & $74 \%$ & $61 \%$ & $66 \%$ & $68 \%$ & $70 \%$ & $68 \%$ & $77 \%$ \\
\hline
\end{tabular}

Source: own elaboration based on: Komunikat z badań (Statement of research) number: 42/2009; 126/2009; 54/2010; 30/2011; 108/2011; 39/2012; 44/2013; 130/2013; 36/2014; 131/2014; 42/2015; 131/2015, CBOS, 
Table 12 Answers "good" among declaring centrist views, 2016-2019

\begin{tabular}{|c|c|c|c|c|c|}
\hline $\begin{array}{c}\text { March } \\
2016\end{array}$ & $\begin{array}{c}\text { March } \\
2017\end{array}$ & $\begin{array}{c}\text { September } \\
2017\end{array}$ & $\begin{array}{c}\text { March } \\
2018\end{array}$ & $\begin{array}{c}\text { September } \\
2018\end{array}$ & $\begin{array}{c}\text { March } \\
2019\end{array}$ \\
\hline $69 \%$ & $61 \%$ & $64 \%$ & $59 \%$ & $67 \%$ & $76 \%$ \\
\hline
\end{tabular}

Source: own elaboration based on: Komunikat z badań (Statement of research) number: 43/2016; 32/2017; 124/2017; 40/2018; 121/2018; 44/2019, CBOS, Warszawa [Warsaw]

Table 13 Average of "good" answers among declaring centrist views, 2009-2015 and 2016-2019

Average of "good" answers among declaring centrist views

\begin{tabular}{|c|c|}
\hline $2009-2015$ & $2016-2019$ \\
\hline $71 \%$ & $66 \%$ \\
\hline
\end{tabular}

Source: own elaboration

Subjects declaring leftist views:

Table 14 Answers "good" declaring among leftist, 2009-2015

\begin{tabular}{|c|c|c|c|c|c|c|c|c|c|c|c|}
\hline $\begin{array}{c}\text { March } \\
2009\end{array}$ & Sept. & April & March & Sept. & March & March & Sept. & March & Sept. & March & Sept. \\
2001 & 2010 & 2011 & 2011 & 2012 & 2013 & 2013 & 2014 & 2014 & 2015 & 2015 \\
\hline $74 \%$ & $67 \%$ & $82 \%$ & $71 \%$ & $70 \%$ & $68 \%$ & $58 \%$ & $73 \%$ & $72 \%$ & $70 \%$ & $64 \%$ & $72 \%$ \\
\hline
\end{tabular}

Source: own elaboration based on: Komunikat z badań (Statement of research) number: 42/2009; 126/2009; 54/2010; 30/2011; 108/2011; 39/2012; 44/2013; 130/2013; 36/2014; 131/2014; 42/2015; 131/2015, CBOS,

Table 15 Answers "good" declaring among leftist, 2016-2019

\begin{tabular}{|c|c|c|c|c|c|}
\hline $\begin{array}{c}\text { March } \\
2016\end{array}$ & $\begin{array}{c}\text { March } \\
2017\end{array}$ & $\begin{array}{c}\text { September } \\
2017\end{array}$ & $\begin{array}{c}\text { March } \\
2018\end{array}$ & $\begin{array}{c}\text { September } \\
2018\end{array}$ & $\begin{array}{c}\text { March } \\
2019\end{array}$ \\
\hline $66 \%$ & $51 \%$ & $57 \%$ & $56 \%$ & $54 \%$ & $63 \%$ \\
\hline
\end{tabular}

Source: own elaboration based on: Komunikat z badań (Statement of research) number: 43/2016; 32/2017; 124/2017; 40/2018; 121/2018; 44/2019, CBOS, Warszawa [Warsaw]

Table 16 Average of "good" answers among declaring leftist views, 2009-2015 and 2016-2019

\begin{tabular}{|c|c|c|}
\hline $\begin{array}{c}\text { Average of "good" answers } \\
\text { among those declaring leftist } \\
\text { views }\end{array}$ & 2009-2015 & 2016-2019 \\
\cline { 2 - 3 } & $70 \%$ & $58 \%$ \\
\hline
\end{tabular}


Subjects declaring right-wing views:

Table 17 Answers "good" declaring among right-wings, 2009-2015

\begin{tabular}{|c|c|c|c|c|c|c|c|c|c|c|c|}
\hline $\begin{array}{c}\text { March } \\
2009\end{array}$ & Sept. & April & March & Sept. & March & March & Sept. & March & Sept. & March & Sept. \\
2014 & 2010 & 2011 & 2011 & 2012 & 2013 & 2013 & 2014 & 2015 & 2015 \\
\hline $81 \%$ & $79 \%$ & $77 \%$ & $64 \%$ & $67 \%$ & $72 \%$ & $59 \%$ & $69 \%$ & $68 \%$ & $70 \%$ & $63 \%$ & $73 \%$ \\
\hline
\end{tabular}

Source: own elaboration based on: Komunikat z badań (Statement of research) number: 42/2009; 126/2009; 54/2010; 30/2011; 108/2011; 39/2012; 44/2013; 130/2013; 36/2014; 131/2014; 42/2015; 131/2015, CBOS, Warszawa [Warsaw]

Table 18 Answers "good" declaring among right-wings, 2016-2019

\begin{tabular}{|c|c|c|c|c|c|}
\hline $\begin{array}{c}\text { March } \\
2016\end{array}$ & March & September & March & September & $\begin{array}{c}\text { March } \\
2019\end{array}$ \\
\hline $73 \%$ & 2017 & 2017 & 2018 & 2018 & $81 \%$ \\
\hline
\end{tabular}

Source: own elaboration based on: Komunikat z badań (Statement of research) number: 43/2016; 32/2017; $124 / 2017 ; 40 / 2018 ; 121 / 2018 ; 44 / 2019$, CBOS, Warszawa [Warsaw]

Table 19 Average of "good" answers among declaring right-wings views, 2009-2015 and 2016-2019

\begin{tabular}{|c|c|c|}
\hline Average of "good" answers & $2009-2015$ & $2016-2019$ \\
\cline { 2 - 3 } among declaring right-wings views & $70 \%$ & $74 \%$ \\
\hline
\end{tabular}

Source: own elaboration

In the case of declaring centrist views, the average "good" answer for 2009-2015 and 2016-2019 decreased by 5 percentage points. Among the declaring leftist views, the average of such answers dropped by 12 percentage points. In the declaring right-wing views, the average "good" answer increased by 4 percentage points. The presented changes, especially those concerning the respondents declaring leftist views, allow to formulate the conclusion that there has been a partial politicization of the social assessment of the activities of the Polish Army.

\section{Answers "bad"}

Subjects declaring centrist views:

Table 20 Answers "bad" declaring among centrist views, 2009-2015

\begin{tabular}{|c|c|c|c|c|c|c|c|c|c|c|c|}
\hline $\begin{array}{c}\text { March } \\
2009\end{array}$ & $\begin{array}{c}\text { Sept. } \\
2009\end{array}$ & $\begin{array}{c}\text { April } \\
2010\end{array}$ & $\begin{array}{c}\text { March } \\
2011\end{array}$ & $\begin{array}{c}\text { Sept. } \\
2011\end{array}$ & $\begin{array}{c}\text { March } \\
2012\end{array}$ & $\begin{array}{c}\text { March } \\
2013\end{array}$ & $\begin{array}{c}\text { Sept. } \\
2013\end{array}$ & $\begin{array}{c}\text { March } \\
2014\end{array}$ & $\begin{array}{c}\text { Sept. } \\
2014\end{array}$ & $\begin{array}{c}\text { March } \\
2015\end{array}$ & $\begin{array}{c}\text { Sept. } \\
2015\end{array}$ \\
\hline $6 \%$ & $9 \%$ & $6 \%$ & $5 \%$ & $8 \%$ & $9 \%$ & $10 \%$ & $3 \%$ & $7 \%$ & $7 \%$ & $6 \%$ & $4 \%$ \\
\hline
\end{tabular}

Source: own elaboration based on: Komunikat z badań (Statement of research) number: 42/2009; 126/2009; 54/2010; 30/2011; 108/2011; 39/2012; 44/2013; 130/2013; 36/2014; 131/2014; 42/2015; 131/2015, CBOS, 
Table 21 Answers "bad" declaring among centrist views, 2016-2019

\begin{tabular}{|c|c|c|c|c|c|}
\hline $\begin{array}{c}\text { March } \\
2016\end{array}$ & $\begin{array}{c}\text { March } \\
2017\end{array}$ & $\begin{array}{c}\text { September } \\
2017\end{array}$ & $\begin{array}{c}\text { March } \\
2018\end{array}$ & $\begin{array}{c}\text { September } \\
2018\end{array}$ & $\begin{array}{c}\text { March } \\
2019\end{array}$ \\
\hline $8 \%$ & $14 \%$ & $14 \%$ & $11 \%$ & $9 \%$ & $11 \%$ \\
\hline
\end{tabular}

Source: own elaboration based on: Komunikat z badań (Statement of research) number: 43/2016; 32/2017; 124/2017; 40/2018; 121/2018; 44/2019; CBOS, Warszawa [Warsaw]

Table 22 Average of "bad" answers among declaring centrist views, 2009-2015 and 2016-2019

\begin{tabular}{|c|c|c|}
\hline \multirow{2}{*}{$\begin{array}{c}\text { Average of "bad" answers among } \\
\text { declaring centrist views }\end{array}$} & $2009-2015$ & $2016-2019$ \\
\cline { 2 - 3 } & $7 \%$ & $11 \%$ \\
\hline
\end{tabular}

Subjects declaring leftist views:

Table 23 Answers "bad" declaring among leftist views, 2009-2015

\begin{tabular}{|c|c|c|c|c|c|c|c|c|c|c|c|}
\hline $\begin{array}{c}\text { March } \\
2009\end{array}$ & $\begin{array}{c}\text { Sept. } \\
2009\end{array}$ & $\begin{array}{c}\text { April } \\
2010\end{array}$ & $\begin{array}{c}\text { March } \\
2011\end{array}$ & $\begin{array}{c}\text { Sept. } \\
2011\end{array}$ & $\begin{array}{c}\text { March } \\
2012\end{array}$ & $\begin{array}{c}\text { March } \\
2013\end{array}$ & $\begin{array}{c}\text { Sept. } \\
2013\end{array}$ & $\begin{array}{c}\text { March } \\
2014\end{array}$ & $\begin{array}{c}\text { Sept. } \\
2014\end{array}$ & $\begin{array}{c}\text { March } \\
2015\end{array}$ & $\begin{array}{c}\text { Sept. } \\
2015\end{array}$ \\
\hline $8 \%$ & $11 \%$ & $5 \%$ & $9 \%$ & $12 \%$ & $14 \%$ & $12 \%$ & $3 \%$ & $13 \%$ & $6 \%$ & $8 \%$ & $6 \%$ \\
\hline
\end{tabular}

Source: own elaboration based on: Komunikat z badań (Statement of research) number: 42/2009; 126/2009; 54/2010; 30/2011; 108/2011; 39/2012; 44/2013; 130/2013; 36/2014; 131/2014; 42/2015; 131/2015, CBOS,

Table 24 Answers "bad" declaring among leftist views, 2009-2015

\begin{tabular}{|c|c|c|c|c|c|}
\hline $\begin{array}{c}\text { March } \\
2016\end{array}$ & $\begin{array}{c}\text { March } \\
2017\end{array}$ & $\begin{array}{c}\text { September } \\
2017\end{array}$ & $\begin{array}{c}\text { March } \\
2018\end{array}$ & $\begin{array}{c}\text { September } \\
2018\end{array}$ & $\begin{array}{c}\text { March } \\
2019\end{array}$ \\
\hline $6 \%$ & $24 \%$ & $22 \%$ & $13 \%$ & $17 \%$ & $22 \%$ \\
\hline
\end{tabular}

Source: own elaboration based on: Komunikat z badań (Statement of research) number: 43/2016; 32/2017; 124/2017; 40/2018; 121/2018; 44/2019, CBOS, Warszawa [Warsaw]

Table 25 Average of "bad" answers among declaring leftist views, 2009-2015 and 2016-2019

\begin{tabular}{|c|c|c|}
\hline \multirow{2}{*}{$\begin{array}{c}\text { Average of "bad" answers among } \\
\text { declaring leftist views }\end{array}$} & $2009-2015$ & $2016-2019$ \\
\cline { 2 - 3 } & $9 \%$ & $17 \%$ \\
\hline
\end{tabular}


Subjects declaring right-wing views:

Table 26 Answers "bad" among declaring right-wing views, 2009-2015

\begin{tabular}{|c|c|c|c|c|c|c|c|c|c|c|c|}
\hline $\begin{array}{c}\text { March } \\
2009\end{array}$ & $\begin{array}{c}\text { Sept. } \\
2009\end{array}$ & $\begin{array}{c}\text { April } \\
2010\end{array}$ & $\begin{array}{c}\text { March } \\
2011\end{array}$ & $\begin{array}{c}\text { Sept. } \\
2011\end{array}$ & $\begin{array}{c}\text { March } \\
2012\end{array}$ & $\begin{array}{c}\text { March } \\
2013\end{array}$ & $\begin{array}{c}\text { Sept. } \\
2013\end{array}$ & $\begin{array}{c}\text { March } \\
2014\end{array}$ & $\begin{array}{c}\text { Sept. } \\
2014\end{array}$ & $\begin{array}{c}\text { March } \\
2015\end{array}$ & $\begin{array}{c}\text { Sept. } \\
2015\end{array}$ \\
\hline $6 \%$ & $7 \%$ & $6 \%$ & $11 \%$ & $9 \%$ & $9 \%$ & $12 \%$ & $6 \%$ & $8 \%$ & $9 \%$ & $10 \%$ & $4 \%$ \\
\hline
\end{tabular}

Source: own elaboration based on: Komunikat z badań (Statement of research) number: 42/2009; 126/2009; 54/2010; 30/2011; 108/2011; 39/2012; 44/2013; 130/2013; 36/2014; 131/2014; 42/2015; 131/2015, CBOS,

Table 27 Answers "bad" among declaring right-wing views, 2016-2019

\begin{tabular}{|c|c|c|c|c|c|}
\hline $\begin{array}{c}\text { March } \\
2016\end{array}$ & $\begin{array}{c}\text { March } \\
2017\end{array}$ & $\begin{array}{c}\text { September } \\
2017\end{array}$ & $\begin{array}{c}\text { March } \\
2018\end{array}$ & $\begin{array}{c}\text { September } \\
2018\end{array}$ & $\begin{array}{c}\text { March } \\
2019\end{array}$ \\
\hline $6 \%$ & $6 \%$ & $7 \%$ & $6 \%$ & $4 \%$ & $5 \%$ \\
\hline
\end{tabular}

Source: own elaboration based on: Komunikat z badań (Statement of research) number: 43/2016; 32/2017; 124/2017; 40/2018; 121/2018; 44/2019, CBOS, Warszawa [Warsaw]

Table 28 Average of "bad" answers among declaring right-wing views, 2009-2015 and 2016-2019

\begin{tabular}{|c|c|c|}
\hline \multirow{2}{*}{$\begin{array}{c}\text { Average of "bad" answers among } \\
\text { declaring right-wing views }\end{array}$} & $2009-2015$ & $2016-2019$ \\
\cline { 2 - 3 } & $8 \%$ & $6 \%$ \\
\hline
\end{tabular}

Source: own elaboration

In the case of declaring centrist views, the average answer "bad" for the years 2009-2015 and 2016-2019 increased by 4 percentage points. Among the declaring leftist views, the average of such responses increased by 8 percentage points. In the declaring right-wing views, the average answer "bad" dropped by 2 percentage points. The presented changes, especially those concerning the respondents declaring leftist views, allow to formulate the conclusion that there has been a partial politicization of the social assessment of the activities of the Polish Army.

Before 2015, the average scores for each group in each category were similar. Answers "hard to say" (average before 2015): center views $23 \%$, leftist views $21 \%$, right-wing views $22 \%$; "good" responses respectively: $71 \%, 70 \%, 70 \%$, "bad" answers respectively: $7 \%, 9 \%, 8 \%$. Since 2016 , there are clear differences in the average ratings of respondents declaring left and right views.

The whole of the data presented in this part of the article clearly shows that after the change of government in the autumn of 2015, there was a partial politicization of the social assessments of the Polish Army. 


\section{Civil and democratic control over the army in the context of the most serious image threats}

Civil and democratic control over the army can be understood as "[...] subordination of the armed forces to the democratically elected political authorities of the state". It consists of several elements:

- it is the responsibility of the civil authorities to create the foreign and defense policy of the state, including deciding on defense doctrines, alliances and military budget;

- subordinating the army to central authorities means that these authorities can make structural and personnel changes in the army;

- in senior military positions, the principle of term is binding, and military positions in the civilian defense center can not be occupied by military personnel;

- civilian authorities are responsible for issues such as modernization, level of armaments, and supervision (it is also the responsibility of the public);

- there is a clear division of competences within the civil authorities. ${ }^{18}$

The legal bases of civil and democratic control over the Polish Army were contained in the Constitution of the Republic of Poland: "The Armed Forces maintain neutrality in political matters and are subject to civil and democratic control". ${ }^{19}$

In the literature on the subject, it is assumed that neutrality in political matters consists of three main elements:

- "not conducting political activities in the army;

- failure to follow political criteria in military activities;

- the military's resistance to any external intervention aimed at using it in political activities" ${ }^{20}$

The constitutional bases of civil and democratic control over the army are also the powers of the President of the Republic of Poland regarding the Polish Army. Of particular importance are the first two paragraphs of Article 134: "1. The President of the Republic is the Supreme Commander of the Armed Forces of the Republic of Poland. 2. During peace, the President of the Republic shall exercise supremacy over the Armed Forces through the Minister of National Defense". In the following paragraphs of this article, the legislator granted the President of the Republic of Poland the power to appoint the Chief of General Staff and commanders of the Armed Forces and, during the war and at the request of the Prime Minister, the Supreme Commander of the Polish Armed Forces. ${ }^{21}$ In addition, in the light of Article 134, the President of the Republic of Poland, at the request of the Minister of National Defense, gives the military grades specified in law. ${ }^{22}$

18 STAŃCZYK, Jerzy: Główne założenia demokratycznej kontroli nad siłami zbrojnymi, in: Problematyka demokratycznej kontroli nad siłami zbrojnymi w wybranych państwach WNP a standardy zachodnie i doświadczenia polskie, STAŃCZYK, Jerzy (ed.), Warszawa [Warsaw] 1999, 11-12.

19 Constitution of the Republic of Poland of 2 April 1997, Dz.U. 1997 No. 78, item 483 with changes, art. 26 , pts. 2.

20 SOKOLEWICZ, Wojciech: Wojsko i Konstytucja, Warszawa [Warsaw] 2015, 65-67.

21 During the war, the appointment of the Supreme Commander of the Polish Armed Forces is obligatory. In the event of the introduction of martial law, the President of the Republic of Poland has the option (not obliged) to appoint the Supreme Commander of the Polish Armed Forces. The Act of 29 August 2002 on Martial Law and on the competences of the Supreme Commander of the Armed Forces and the principles of its subordination to the constitutional organs of the Republic of Poland, Dz.U. 2002 No. 156 item 1301 with changes, art. 10, point 2, par. 4.

22 Constitution of the Republic of Poland of 2 April 1997, Dz.U. 1997 No. 78, item 483 with changes, art. 134. 
The principle of civil and democratic control in addition to constitutional authorization has also been expressed in statutes. Of particular importance is the first article of the Act of 14 December 1995 on the Office of the Minister of National Defense: "The Minister of National Defense heads the government administration department and defends the national authority, through which the President of the Republic of Poland exercises supreme control over the Armed Forces of the Republic of Poland; hereafter referred to as "Armed Forces". 2. The Minister of National Defense performs his tasks with the help of the Ministry of National Defense, hereinafter referred to as the "Ministry", which includes the General Staff of the Polish Army". ${ }^{23}$

Legal solutions and practice clearly indicate the full subordination of the Polish Army to democratically elected civil authorities. At the same time, civil authorities generated, generate and in the future may generate image threats for the army. Examples of such threats have been demonstrated in the previous part of the article. These threats are the result of political decisions that are taken independently of the military - this leads to a situation in which the military does not take decisions and is burdened with their image costs. At the same time, Army has limited possibilities to counteract the negative image effects of political decisions. It can (and should) carry out information and promotional activities, presenting itself as a professional and non-politicized institution. However, he can not be an active player in political activities. The constitutional principle of "neutrality in political matters" makes it impossible for the military to undertake political activities that can combat the image threats posed by political decisions. The military can not take action to change the social perception of the army resulting from political views.

Actions that the army can not undertake, can take civilian authority. If power generates political threats to the army and the military can counteract these threats to a limited extent, the responsibility for depoliticising the image of the army should rest with the rulers. Civilian authority should not only steer and control the army, but should also protect it from the image-related effects of political decisions. A way to implement this postulate could be to introduce two independent communication divisions within the Ministry of National Defense. One would be responsible for the content related to informing about the activities of the army and its promotion. The second would be responsible for political messages independent of the army, aimed at providing the army with protection against the negative effects of political decisions.

\section{Conclusions}

The article analyzes the most important threats to the image of the Polish Army in 20092019. It was shown that these threats are related to the political sphere - they concern political decisions (such as socially unacceptable participation in missions in Iraq and Afghanistan) and partly politicized social evaluation of military activity. The way of understanding and the legal basis of civil and democratic control over the army in Poland is also presented.

The work assumes the hypothesis that in order to counteract the most serious image threats, there should be an extension of civilian meaning and democratic control over the

23 The Act of 14 December 1995 on the Office of the Minister of National Defense, Dz.U. 1996 No. 10, item 56 with changes. 
army. This control should include actions of state authorities protecting the military from the negative image-related effects of political decisions and ongoing political rivalry. In the author's opinion, this hypothesis was verified positively. Threats to the image of the army resulting from political reasons were, are and potentially will be real. The military may, due to the inability to engage in political affairs, oppose such threats only to a limited extent. Thus, the prevention of political threats should rest on civil authority. The military as an institution established to defend the state and citizens (regardless of their views) can not be a subject of political struggle. Civilian authority should therefore protect the military against the effects of its political decisions.

\section{References}

\section{Komunikat z badań (Statement of research)}

- Komunikat z badań (Statement of research) number: 134/2007, CBOS Warszawa [Warsaw]

- Komunikat z badań (Statement of research) number: 162/2007, CBOS Warszawa [Warsaw]

- Komunikat z badań (Statement of research) number: 42/2009, CBOS Warszawa [Warsaw]

- Komunikat z badań (Statement of research) number: 126/2009, CBOS Warszawa [Warsaw]

- Komunikat z badań (Statement of research) number: 127/2009, CBOS Warszawa [Warsaw]

- Komunikat z badań (Statement of research) number: 144/2009, CBOS Warszawa [Warsaw]

- Komunikat z badań (Statement of research) number: 54/2010, CBOS Warszawa [Warsaw]

- Komunikat z badań (Statement of research) number: 159/2010, CBOS Warszawa [Warsaw]

- Komunikat z badań (Statement of research) number: 30/2011, CBOS Warszawa [Warsaw]

- Komunikat z badań (Statement of research) number: 108/2011, CBOS Warszawa [Warsaw]

- Komunikat z badań (Statement of research) number: 39/2012, CBOS Warszawa [Warsaw]

- Komunikat z badań (Statement of research) number: 44/2013, CBOS Warszawa [Warsaw]

- Komunikat z badań (Statement of research) number: 130/2013, CBOS Warszawa [Warsaw]

- Komunikat z badań (Statement of research) number: 36/2014, CBOS Warszawa [Warsaw]

- Komunikat z badań (Statement of research) number: 131/2014, CBOS Warszawa [Warsaw]

- Komunikat z badań (Statement of research) number: 42/2015, CBOS Warszawa [Warsaw]

- Komunikat z badań (Statement of research) number: 131/2015, CBOS Warszawa [Warsaw]

- Komunikat z badań (Statement of research) number: 43/2016, CBOS Warszawa [Warsaw]

- Komunikat z badań (Statement of research) number: 32/2017, CBOS Warszawa [Warsaw]

- Komunikat z badań (Statement of research) number: 124/2017, CBOS Warszawa [Warsaw]

- Komunikat z badań (Statement of research) number: 40/2018, CBOS Warszawa [Warsaw]

- Komunikat z badań (Statement of research) number: 121/2018, CBOS Warszawa [Warsaw]

- Komunikat z badań (Statement of research) number: 44/2019, CBOS Warszawa [Warsaw]

Constitution of the Republic of Poland of 2 April 1997, Dz.U. 1997 No. 78, item 483 with changes.

Decision of the Minister of National Defence No. 108/MON of 7 April 2009 on the principles of implementing the information policy of the Ministry of National Defence, Official Journal of the Minister of National Defence, 2009, No. 7, item 82. 
Decision of the Minister of National Defence No. 47/MON of 26 March 2019 on the principles of implementing the information policy and functioning of the social communication service in the Ministry of National Defence, Official Journal of the Minister of National Defence, 2019, item 56.

KLEIN, Grzegorz: Obraz Wojska Polskiego w prasie w świetle zaangażowania w misje poza granicami kraju, in: Zeszyty Naukowe Bezpieczeństwo i Administracja, 2014, 4, 219. KLEIN, Grzegorz: Kształtowanie wizerunku Wojska Polskiego jako instytucji zapewniającej bezpieczeństwo, Warszawa [Warsaw] 2019.

Metody realizacji badań (Research realization methods), online: https://www.cbos.pl/PL/ badania/metody_realizacji.php.

National Security Strategy of the Republic of Poland, Warsaw 2014.

Research, online: https://www.cbos.pl/EN/research/research.php.

SOKOLEWICZ, Wojciech: Wojsko i Konstytucja, Warszawa [Warsaw] 2015.

STAŃCZYK, Jerzy: Główne założenia demokratycznej kontroli nad siłami zbrojnymi, in: Problematyka demokratycznej kontroli nad siłami zbrojnymi w wybranych państwach WNP a standardy zachodnie i doświadczenia polskie, STAŃCZYK, Jerzy (ed.), Warszawa [Warsaw] 1999, 11-12.

The Act of 14 December 1995 on the Office of the Minister of National Defense, Dz.U. 1996 No. 10, item 56 with changes.

The Act of 29 August 2002 on Martial Law and on the competences of the Supreme Commander of the Armed Forces and the principles of its subordination to the constitutional organs of the Republic of Poland, Dz.U. 2002 No. 156 item 1301 with changes.

\section{Author}

Grzegorz Klein, PhD.

Wydział Administracji i Bezpieczeństwa Narodowego, Akademia im. Jakuba z Paradyża Department of Administration and National Security, The Jacob of Paradies University ul. Teatralna 25, 66-400 Gorzów Wielkopolski, Poland grzegorz.klein@gmail.com 